\title{
ISOLATION AND CHARACTERIZATION OF TRIACYLGLYCEROL ACCUMULATING MICROORGANISMS FOR BIODIESEL PRODUCTION
}

\section{Sony Adhi Susanto}

Institut Teknologi Del, Jl. Sisingamangaraja, Sitoluama, Laguboti, Toba Samosir Regency, North Sumatera, Postal Code: 22381.

Received - January 16, 2017; Revision- February 16, 2017; Accepted - February 21, 2017

Available Online - February 28, 2017

DOI: http://dx.doi.org/10.18006/2017.5(1).111.119

\section{KEYWORDS}

Triacylglycerol

Biodiesel

Oleaginous microorganisms

Nile red

Thin layer chromatography (TLC)

High performance liquid chromatography (HPLC)

\begin{abstract}
Triacylglycerol is an important feedstock for biodiesel production. In this study, several strains of oleaginous bacteria were isolated from environmental sample based on their ability to grow on mineral salts medium supplemented with wood derived sugars such as cellulose, arabinose, xylose, mannose, and galactose. The lipid accumulating bacteria were selected on the basis of fluorescent signal from hydrophobic inclusion in the cytoplasm after incubation in selective medium containing lipophilic dye $0.5 \%$ (w/v) nile red. The lipid content was analyzed using thin layer chromatography (TLC) and gas chromatography-mass spectrometry (GC-MS). In this study, three bacterial isolates 2HPCS1R4, 1LPCS2R2, and 1LPCS2R14 were selected among several studied candidates. TLC analysis of hydrophobic substance from 1LPCS2R2 and 1LPCS2R14 showed two overlapped discrete bands corresponded to triacylglycerol reference band, while 2HPCS1R4 displayed a faint band located above the reference band. GC-MS analysis confirmed that the bands consisted of fatty acid methyl esters with alkyl length varied from $\mathrm{C} 12$ to $\mathrm{C} 17$. Kinetic study showed that the fastest growing strain was 1LPCS2R2 had the highest growth rates and grown in glucose $\left(\mu=0.29 \mathrm{~h}^{-1}\right)$ and xylose $\left(\mu=0.16 \mathrm{~h}^{-1}\right)$. In conclusion, this study has identified of prospective bacterial isolates for commercial biodiesel production.
\end{abstract}

* Corresponding author

E-mail: sony.susanto@outlook.com; sony.susanto@del.ac.id (Sony Adhi Susanto)

Peer review under responsibility of Journal of Experimental Biology and Agricultural Sciences.

Production and Hosting by Horizon Publisher India [HPI] (http://www.horizonpublisherindia.in/).

All rights reserved.
All the article published by Journal of Experimental Biology and Agricultural Sciences is licensed under a Creative Commons Attribution-NonCommercial 4.0 International License Based on a work at www.jebas.org.

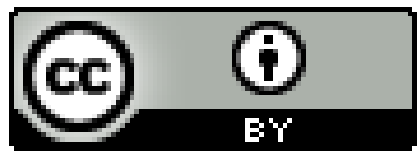




\section{Introduction}

Agriculture and plantation are the most important economic sector in Indonesia. Palm oil and pulp-paper industry contributes to almost US\$ 31.27 billion from total of US\$ 86.01 billion of Indonesian's export (Kemenperin, 2016). By the year of 2013, Indonesia had become the second largest palm oil producer after Malaysia with total production of 12 million tons of crude palm oil (CPO) accounted to $44 \%$ of total world CPO production (FAO, 2016). The higher production rate is also followed by significant amount of waste. Most of the agriculture and plantation waste is lignocellulosic biomass. It is a recalcitrant substance served as structural backbone of plant cells and composed of cellulose (40\%-50\%) and hemicellulose $(25 \%-30 \%)$ bound together by lignin (15\% 20\%) (Bugg et al., 2011; Brethauer \& Studer, 2015).

Due to the recalcitrant nature of the lignocellulosic biomass, pretreatment is required to degrade the overall structure of the biomass in order to release fermentable sugars for energy and carbon source for microbial-based biotechnological processes (Wyman, 2003). Till date, there are several established pretreatment technologies which are described elsewhere (Jönsson \& Martín, 2015). One of them is acid hydrolysis that converts lignocellulosic biomass to polysaccharides such as cellulose, hemicellulose and monosaccharides such as arabinose, xylose, mannose, galactose and glucose and the composition varied based on the concentration of the acid and the enzyme (Cara et al., 2008). These compounds can serve as cheap and abundant carbon source which is required for bulk low cost biodiesel production.

Biodiesel consists of mono alkyl esters of long-fatty acids with short-chain alcohols such as methanol or ethanol which constitute fatty acid methyl esters (FAMEs) or fatty acid ethyl esters (FAEEs) respectively. Though biodiesel has several advantages over petroleum diesel, commercialization of this environmental friendly energy is still limited (a detail discussion is available elsewhere) (Krawczyk, 1996). Production costs, sustainability and geographic-dependent availability of feedstock are the main reason of the hurdle. Therefore, the use of lignocellulosic biomass can reduce the production cost. Some of the lignocellulosic biomass are available as underutilized waste in agriculture, plantation and wood-related industry. Low cost bioconversion using oleaginous microorganisms, that utilize the feedstock for biodiesel production, can give alternative solution for the issue (Yousuf, 2012). Therefore present research was aimed to screen and characterize potential microorganisms which were able to utilize wood-derived sugars as energy and carbon source to accumulate triglyceride as feedstock for biodiesel production.

\section{Materials and Methods}

Environmental sample from various sources such as compost and sludge were collected and then the materials were incubated in screening medium supplemented with woodderived sugars such as cellulose, xylose, arabinose, and glucose. Oleaginous microorganisms were screened using microscope fluorescence and validated by thin layer chromatography (TLC) and gas chromatography - mass spectrometry (GC-MS).

\subsection{Samples}

Samples were collected from late stage compost soil located at composting facility in municipal garden located at Komplek Perumahan Dosen ITB, Jl. Kanayakan, Bandung, Indonesia. The sewage sludge was collected from waste water and shrimps ponds in Perumahan Kompleks Pertamina Klayan, Gunung Jati, Cirebon of Indonesia. All the collected samples were stored at $4^{\circ} \mathrm{C}$.

\subsection{Screening of Cellulosic Biomass Utilizing Microorganisms}

In order to isolate bacteria which were capable to utilize cellulosic biomass, $2 \mathrm{ml}$ of re-suspended sludge sample and $2 \mathrm{~g}$ of each compost soil were enriched in $200 \mathrm{ml}$ of mineral salts medium (MSM), the high phosphate MSM (HPMSM) (Schlegel et al., 1961) and the low phosphate MSM (LPMSM) (Nicholson \& Fathepure, 2004). Each was supplemented with $2 \%(\mathrm{w} / \mathrm{v})$ cellulose and starch as the sole carbon source. The aerobic incubation was then performed in temperaturecontrolled room $\left(30^{\circ} \mathrm{C}\right)$ for 48 hours. The selection of microorganisms were conducted by transferring $500 \mu 1$ of the liquid media containing selectively enriched microbes into agar plate HPMSM and LPMSM, each supplemented with $2 \%$ (w/v) of cellulose, arabinose, xylose, mannose, and galactose as the sole carbon source. The plates were incubated at $30^{\circ} \mathrm{C}$ for $4-7$ days until the bacterial colonies were grown. In order to obtain axenic cultures, the mixed culture colonies were streaked for three times. To store the selected bacteria, $2 \mathrm{ml}$ of $10 \%(\mathrm{w} / \mathrm{v}$ ) sterile skim milk (Difco) was added to the bacteria grown in solid agar media, transferred to the cryo vial tube containing several sterile paper disc. The bacterial cells were freezed for at least 6 hours at $-20^{\circ} \mathrm{C}$ then lyophilized with freeze dryer. The bacterial strains were then stored at $-80^{\circ} \mathrm{C}$.

2.3 Screening of Hydrophobic Substance Accumulating Microorganisms

Lipid granule which is intracellularly accumulated by certain microorganisms can be visualized using lipophilic stain, nile red, bound specifically with hydrophobic substances like lipid, wax esters, and polyhydroxyalkanoate. Modification of original method (Spiekermann et al., 1999) was employed during this study. The detail of the protocol is as the following: Nile red (Biochemika) was dissolved with dimethyl sulfoxide (DMSO) to give final concentration of $0.5 \%(\mathrm{w} / \mathrm{v})$. The selected microorganisms were incubated in this solution for at least 5 minutes. Afterwards, the hydrophobic granules were 
observed under fluorescence microscope (Carl Zeiss) at a wavelength of $598 \mathrm{~nm}$.

\subsection{Thin Layer Chromatography}

Thin layer chromatography (TLC) was performed to rapidly characterize the hydrophobic content of the sample from bacterial isolates acquired from the microscope fluorescence screening. The technique was modification of established methods which is described elsewhere (Uthoff \& Stöveken, 2005). The detail of the method is as followed. The bacterial cell candidate was firstly incubated in $-20^{\circ} \mathrm{C}$ for at least 12 hours. Afterwards, the frozen cells were dried using freeze dryer for at least 12 hours. The biomass was pulverized. Hydrophobic extraction was performed by weighing approximately $10 \mathrm{mg}$ of the cell powder and mixed it with $1 \mathrm{ml}$ of chloroform : methanol (2:1) in a microtube. Afterwards, the mixture was rigorously mixed with vibromixer for 1 minute at room temperature. In order to separate the extracted hydrophobic-rich substances from the rest of the cell biomass, the mixture was centrifuged for 10 minutes at $13,000 \mathrm{rpm}$. Afterwards, the extraction procedure was repeated with the rest of the cell biomass.

The second supernatant was mixed with the first, afterwards it was evaporated until the volume achieve to approximately 0.2 $\mathrm{ml}$. The sample was applied to the silica gel plate (Silica Gel 60, DC Kieselgel 60, Merck). Afterwards the plate was incubated in air-tight closed container containing mobile phase mixture composed of hexane : diethyl ether : acetic acid (90 : $10: 1 \mathrm{v} / \mathrm{v} / \mathrm{v})$. Sample visualization was performed by exposing the plate with iodine vapour to characterize the unsaturated fatty acids (Alvarez et al., 1997). To detect lipid fractions which did not contain double bond (saturated fatty acids), the sample was sprayed with $30 \%(\mathrm{v} / \mathrm{v})$ aqueous sulfuric acid and heated in an oven to $200^{\circ} \mathrm{C}$ until the spot is visualized (Uthoff \& Stöveken, 2005).

\subsection{Gas Chromatography - Mass Spectrometry}

The lipid content of the bacterial cell, which accumulating hydrophobic granule, was analyzed using gas chromatography -mass spectroscopy (GC-MS). The method was modification in a method described by Ibrahim \& Steinbüchel (2009). The detail of method is described as followed: The selected isolates, contained large hydrophobic granule, were frozen at $20^{\circ} \mathrm{C}$. Afterwards, the cells was lyophilized for a minimum of 24 hours. The cell was pulverized and $10 \mathrm{mg}$ was transferred to a test tube. Alternatively, the hydrophobic content of the lyophilized cell was firstly separated with TLC, then the expected bands were scratched and $10 \mathrm{mg}$ of the powder was transferred to test tubes. Afterwards, methanolysis procedure was performed to convert the lipid sample to volatile derivative. To achieve this goal, $1 \mathrm{ml}$ of a mixture of $85 \%(\mathrm{v} / \mathrm{v})$ methanol and $15 \%(\mathrm{v} / \mathrm{v})$ sulfuric acid was added, incubated at $100^{\circ} \mathrm{C}$ for 4 hours. Water was added to the reaction product to dissolve and separate the hydrophilic portion. A $3 \mu 1$ organic phase was analyzed with GC-MS instrument after split less injection. The instrument was Series 6890 GC system equipped with a series 5973 EiMSD mass-selective detector (Hewlett Packard). The column was BPX 35 capillary column (60 m x $250 \mu \mathrm{m}$, film thickness $250 \mu \mathrm{m}$ (SGE Analytical Science). The carrier gas was helium, constant flow of 0.6 $\mathrm{ml} / \mathrm{min}$. The temperature injector and detector were $250^{\circ} \mathrm{C}$ and $240^{\circ} \mathrm{C}$, respectively. The following temperature program was applied: $120^{\circ} \mathrm{C}$ for $5 \mathrm{mins}$, increased by $3^{\circ} \mathrm{C} / \mathrm{mins}$ to $180^{\circ} \mathrm{C}$ and by $10^{\circ} \mathrm{C} / \mathrm{mins}$ to $220^{\circ} \mathrm{C}$. The data were compared with NIST-Mass Spectral Search Program available online at http://chemdata.nist.gov/mass-spc/ms-search/.

\subsection{Growth Experiment}

Growth experiments were conducted to determine growth curve and rate of the selected strains. Three selected bacterial strains were pre-enriched in $10 \mathrm{ml}$ of nutrient agar medium (Oxoid) for $12-16$ hours at constant temperature of $30^{\circ} \mathrm{C}$, shaking incubator $144 \mathrm{rpm}$. Afterwards, the pre-enriched culture was inoculated to $200 \mathrm{ml}$ of respective mineral salts medium supplemented with $2 \%$ (w/v) xylose or glucose in 11 of klett flask. The cultivation was performed at $30^{\circ} \mathrm{C}$, within 35 hours. The turbidity of the growth culture was measured using klett colorimeter (Manostat Corporation). The data was processed with Microsoft ${ }^{\circledR}$ Excel. The klett unit was converted to natural logarithm and plotted against incubation time in hours. In order to derive the growth rate, linear regression line was calculated through the log phase and the rate was deduced from the slope.

\section{Results}

\subsection{Selection of Microorganisms}

In this study, among 50 isolates which we have selected, three of them showed interesting properties (Table 1).

Table1 Selected Bacterial Isolates and Their Properties.

\begin{tabular}{|llll|}
\hline Strain Identifier & Source $^{1}$ & Salinity & MSM \\
\hline 1LPCS2R2 & Compost & $1 \%(w / v)$ & Low phosphate \\
\hline 1LPCS2R14 & Compost & $1 \%(w / v)$ & Low phosphate \\
\hline 2HPCS1R4 & Sludge & $2 \%(w / v)$ & High phosphate \\
\hline
\end{tabular}

${ }^{I}$ The location where the bacterial sample was isolated. Compost was derived from composting facility, and sludge was derived from shrimp's pond].

All of them were able to use $2 \%(w / v)$ cellulose as sole carbon source. Two of them were derived from low phosphate MSM, while the other was selected from the high phosphate selective medium. All isolated bacterial cultures were able to live in the high salinity medium. 

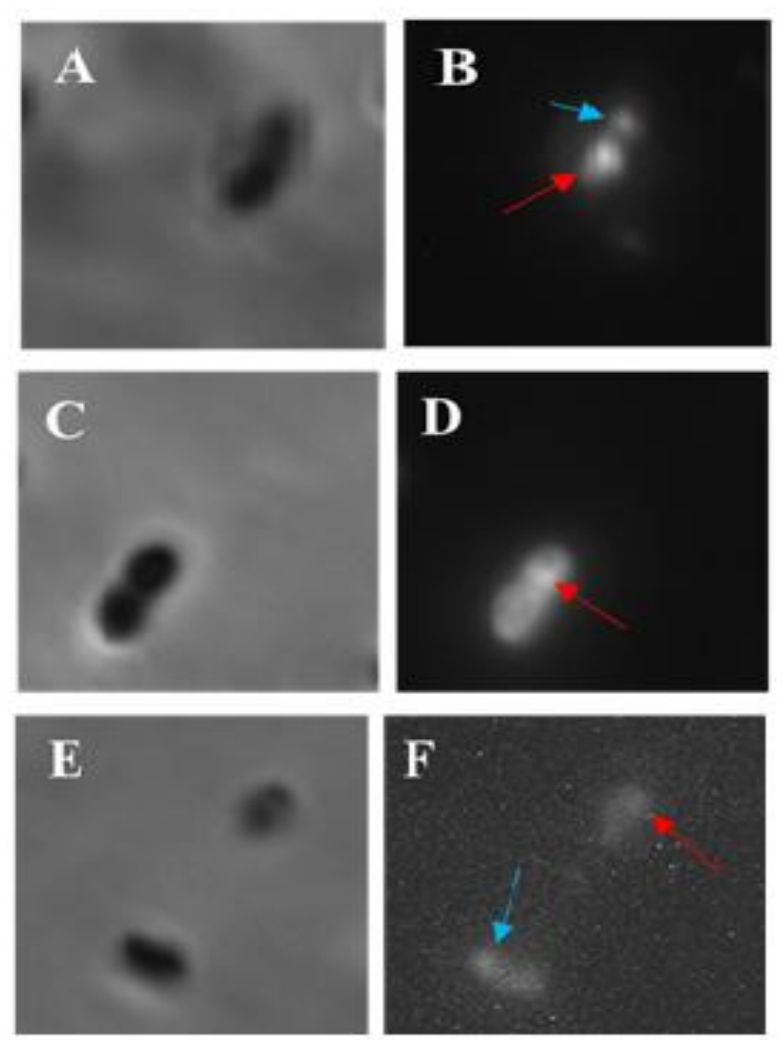

Figure 1 Fluorescence microscopy observation of three selected bacterial isolates (A) and (B) 2HPCS1R4, (C) and (D) 1LPCS2R2, (E) and (F) 1LPCS2R14.

[(A), (C) and (E) Light and (B), (D) and $(F)$ fluorescence image of the respected bacterial strain: The white signal (red arrows) in the cytoplasm of bacterial cells was derived from interaction of a lipophilic dye (nile red) with hydrophobic substances. 2HPCS1R4 had two kinds of hydrophobic inclusion (B) (red and blue arrows). Whereas 1LPCS2R2 and 1LPCS2R14 had mainly membrane fluorescence (D), (F).Original magnification $x$ 400].

\subsection{Hydrophobic Inclusion}

Lipophilic dye, nile red, penetrated the plasma membrane of the selected cells and bound to the hydrophobic compound. Monochromatic light with a wavelength of $598 \mathrm{~nm}$ excited the non-polar substances bound nile red in the cells. The emission light was detected with microscope fluorescence and the results of the observation indicated variety of hydrophobic substances in the cells (Figure 1). Bacterial strain 2HPCS1R4 contained two hydrophobic inclusions (Figure 1B, red and blue arrow) in the cytoplasm. Whereas, the hydrophobic inclusion in 1LPCS2R2 was distributed around the plasma membrane (Figure 1D, arrow). A small discrete inclusion was found at the edge of the cells (Figure 1D). Similarly, 1LPCS2R14 showed faint distributed inclusion (Figure $1 \mathrm{~F}$ ), and small discrete inclusion (Figure 1F, blue arrow).
3.3 Analysis of Hydrophobic Inclusion with Thin Layer Chromatography

Treatment of $10 \mathrm{mg}$ of cell dry mass of 1LPCS2R14, 1LPCS2R2 (Figure 2) and 2HPCS1R4 (Figure 3) with organic solvent (chloroform: methanol) released the hydrophobic content of the cells.

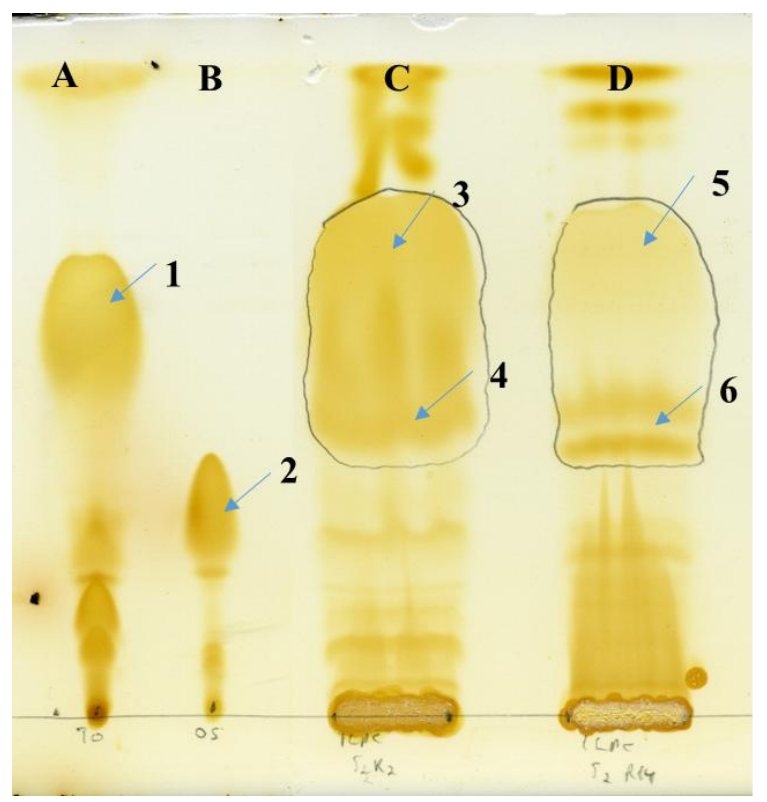

Figure 2 Thin layer chromatography (TLC) of hydrophobic content from selected bacterial isolates.

[(A) Triolein, (B) oleic acid. They were served as TLC standard of triglyceride (arrow 1) and free fatty acids (arrow 2) respectively. (C) TLC of hydrophobic content of 1LPCS2R2. Chloroform-methanol-exracted $10 \mathrm{mg}$ of $1 \mathrm{LPCS} 2 \mathrm{R} 2$ cell dry mass was analyzed with TLC. Two discrete bands (arrow 3, 4), which were overlapped each other, were observed after incubation of the TLC plate with iodine. (D) TLC of hydrophobic content of 1LPCS2R14. Chloroform-methanolextracted $10 \mathrm{mg}$ of 1LPCS2R14 cell dry mass was analyzed with TLC. Three obvious discrete bands (arrow 5, 6) were detected].

In the TLC plate, the mixture of hydrophobic compound was separated using silica gel plates using mobile phase composed of hexane/diethyl ether/acetic acid. 1LPCS2R2 contained triolein like hydrophobic compound (Figure 2, arrow 3) and oleic acid-like hydrophobic compound (Figure 2, arrow 4) which were overlapped to each other. Whereas, 1LPCS2R14 gave faint triolein-like hydrophobic band (Figure 2, arrow 5) and two discrete bands of oleic acid-like (Figure 2, arrow 6). These respective bands lay slightly above the control bands. The 2HPCS1R4 contained different hydrophobic substances which was comparably different with the previous two. The discrete band lay above the triolein-like hydrophobic band (Figure 3, arrow 3). 


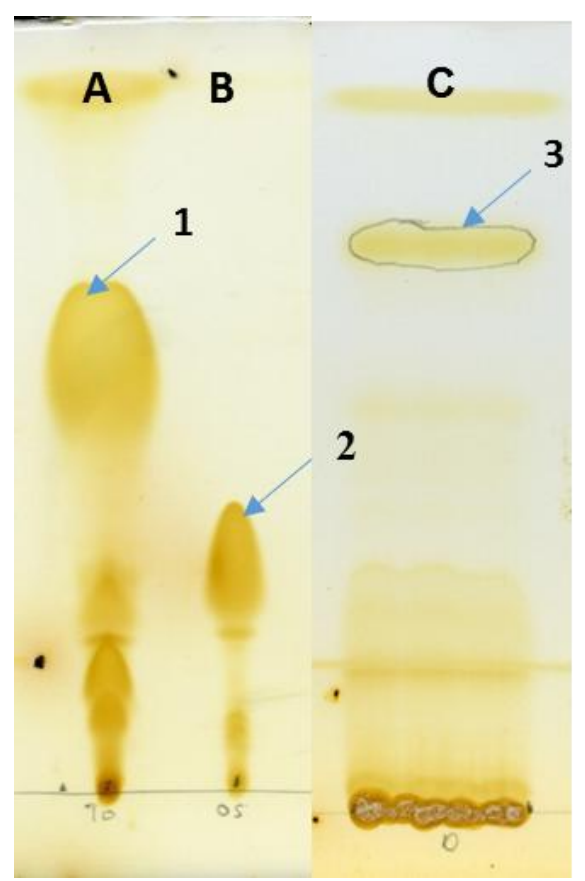

Figure 3 Thin layer chroma-tography (TLC) of hydrophobic content from 2HPCS1R4.

[(A) Triolein, (B) oleic acid. They were served as TLC standard of triglyceride (arrow 1) and free fatty acids (arrow 2) respectively. (C) TLC of hydrophobic content of 2HPCS1R4. Chloroform-methanol-extracted $10 \mathrm{mg}$ of 2HPCS1R4 cell dry mass was analyzed with TLC. A discrete band (arrow 3) was detected just above the triolein standard.].

\subsection{Gas chromatography analysis}

The elucidation of the identity of the hydrophobic compound in the TLC bands showed mixtures of different long chain fatty acid residues. The two discrete bands derived from bacterial strain 1LPCS2R2 (Figure 2, arrow 3 and 4) revealed some mixtures of methyl ester ranged from myristic acid (tetradecanoic acid) methyl ester (C14) (Figure 4, peak A), small amount of pentadecanoic acid methyl ester (C15) (Figure 4, peak C, E), branched lauric acid (dodecanoic acid) methyl ester (Figure 4, peak D), palmitic acid (hexadecanoic acid) methyl ester (Figure 4, peak F, G, H).

GC-MS analysis of two discrete bands from 1LPCS2R14 (Figure 2, arrow 5,6) showed some mixtures of fatty acid methyl ester predominantly composed of lauric acid (dodecanoic acid) methyl ester (C12) (Figure 5, peak C), myristic (tetradecanoic acid) methyl ester (C14) (Figure 5, peak D, F), pentadecylic acid methyl ester (C15) (Figure 5, peak E, G), palmitic acid (hexadecanoic acid) methyl ester (Figure 5, peak $\mathrm{H}$ ), and margaric acid (heptadecanoic acid) methyl ester (Figure 5, peak I)

Whereas, GC-MS analysis of hydrophobic substances in the cytoplasm of 2HPCS2R4 showed only few recognizable peaks
(Figure 6). They were palmitic acid (hexadecanoic acid) methyl ester (Figure 6, peak A), oleyl alcohol (Figure 6, peak B), and stearic acid (octadecanoic acid) methyl ester (Figure 6, peak C).

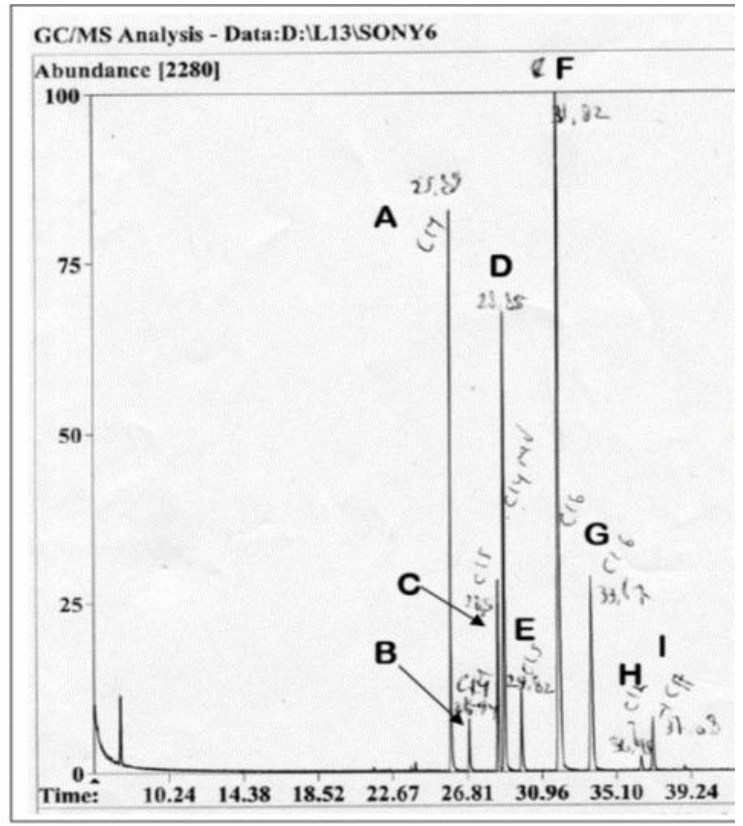

Figure 4 Gas chromatography - mass spectroscopy analysis of hydrophobic content of 1LPCS2R2. The hydrophobic content derived from discrete bands shown in Figure 2, arrow 5 and 6. The chromatogram showed different length of fatty acids of methyl ester ranged from $\mathrm{C} 14$ to $\mathrm{C} 16$.

[Peak A (ret. time 25.89 min.) and peak B (ret. time 26.94 min.) were methyl tetradecanoate; peak $C$ (ret. time 28.5 min.) and peak $E$ (ret. time $29.86 \mathrm{~min}$.) were methyl pentadecanoate; peak D (ret. time 28.85 min.) was 12 -methyl- methyl tetradecanoate; peak $F$ (ret. time $31.82 \mathrm{~min}$ ) and peak $G$ (ret. time 33.67 min.) were methyl hexadecanoate: peak $H$ (ret. time 36.45 min.) was 8 methyl- methyl decanoate].

\subsection{Growth Kinetic of Selected Bacterial Isolates}

In order to evaluate whether the selected isolates are suitable for the industrial process, growth kinetic of selected bacterial isolates was investigated by incubating them in $2 \%(\mathrm{w} / \mathrm{v})$ glucose and xylose. 1LPCS2R14 showed different growth patterns, when glucose was used as a sole carbon source (Figure 7A), the log phase of 1LPCS2R14 commenced quite early, around $3^{\text {rd }}$ to $23^{\text {rd }}$ hours after inoculation. The calculated line of regression linear spanned the indicated times was $\mathrm{y}=$ $0.0469 \mathrm{X}+3.8869$, so that doubling time was $0.049 \mathrm{~h}^{-1}$. 1LPCS2R14 grew in xylose with doubling rates of $0.0248 \mathrm{~h}^{-1}$. The log phase spanned throughout the measuring time (Figure $7 \mathrm{~B})$, however the linearity of the regression line from natural logarithm of klett unit vs incubation time was low $\left(\mathrm{R}^{2}=\right.$ 0.9016). 1LPCS2R4 incubated in $2 \%(\mathrm{w} / \mathrm{v})$ glucose showed defined growth curve (Figure 7C). 


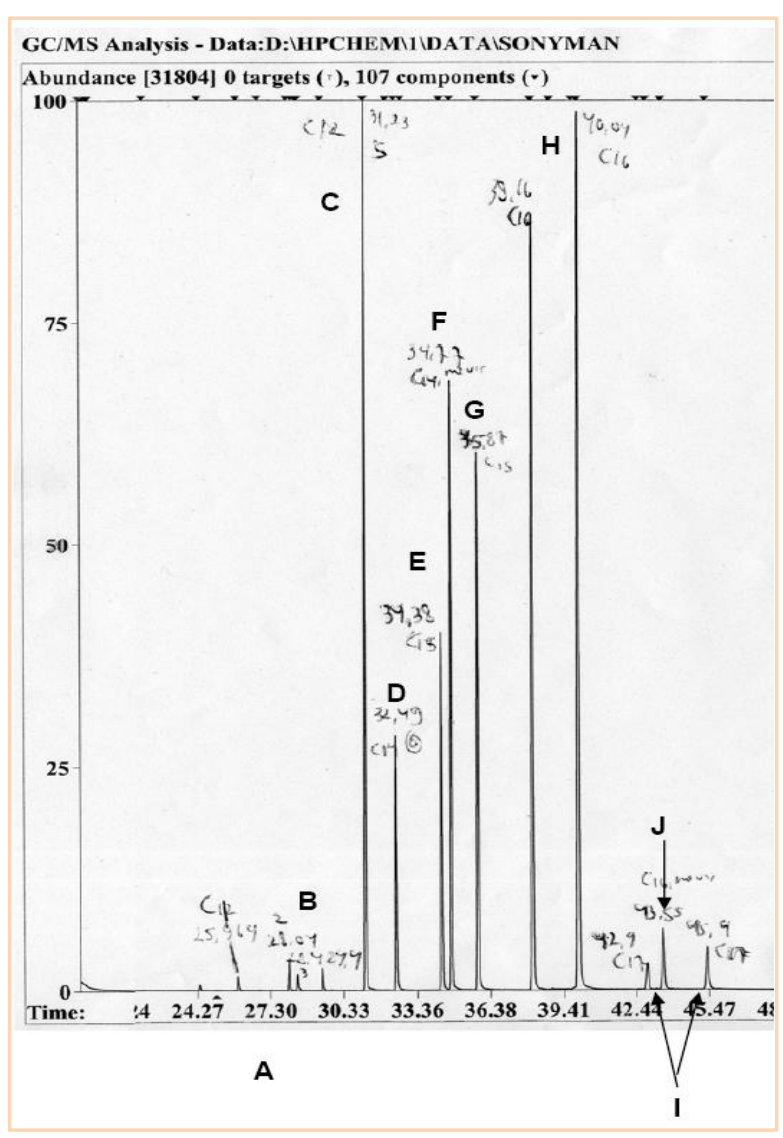

Figure 5 Gas chromatography - mass spectroscopy analysis of hydrophobic content of 1LPCS2R14. The hydrophobic content originated from TLC bands shown in Figure 2, arrow 5. The chromatogram showed different length of fatty acids of methyl ester ranged from predominantly $\mathrm{C} 12$ to $\mathrm{C} 17$. [Peak A (ret. time $25.97 \mathrm{~min}$.) and $C$ (ret. time $31.23 \mathrm{~min}$.) were methyldodecanoate; peak $B$ (ret. time $28.04 \mathrm{~min}$.) was methyl tridecanoate; peak $D$ (ret. time $32,49 \mathrm{~min}$.) was methyl tetradecanoate; peak $E$ (ret. time 34.38 min.) was methyl pentade-canoate; peak $F$ (ret. time 24.73 min.) and peak $G$ (ret. time 35.87 min.) were methyl hexadecanoate; peak $H$ (ret. time $40.04 \mathrm{~min}$ ) and peak $J$ (ret. time $43.85 \mathrm{~min}$.) were 8methyl methyl decanoate.]

The exponential phase was detected at $12^{\text {th }}-18^{\text {th }}$ hours of incubation time. The rate of doubling time as appeared in the $\log$ phase was $0.29 \mathrm{~h}^{-1}$. When the isolate was incubated in $2 \%$ (w/v) xylose (Figure 7D), the doubling time was decreased to $0.17 \mathrm{~h}^{-1}$ and the log phase started at the early phase. No lag phase was observed in the growth curve. Similarly, log phase of 2HPCS1R14 (Figure 7E), started at the early phase, $\left(0-15^{\text {th }}\right.$ hours of incubation time). The growth rate of the isolates was $0.16 \mathrm{~h}^{-1}$. However, 2HPCS1R14 was grown in 2\% (w/v) xylose (Figure 7F), the doubling rate decreased dramatically to 0.089 $\mathrm{h}^{-1}$.

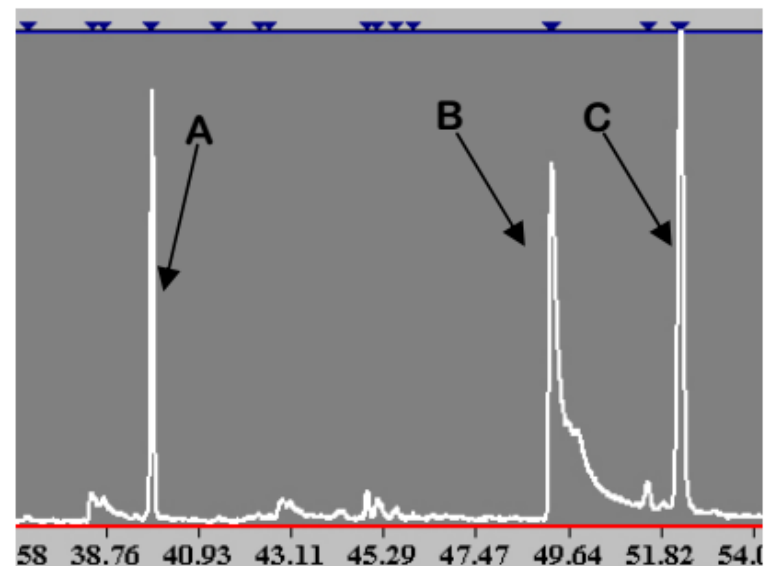

Figure 6 Gas chromatography - mass spectroscopy analysis of hydrophobic content from 2HPCS1R4. The gas chromatography analysis of discrete band (Figure 3, arrow 3) showed three major distinct peaks,

[(A)hexadecanoic acid (C16), (B) oleyl alcohol (C8), and (C) octadecanoic acid (C18).]

\section{Discussions}

In this study, some potential bacterial strains were isolated from sludge of municipal sewage, 2HPCS1R4, and two bacterial strains from late phase of compost soil, 1LPCS2R2 and 1LPCS2R14. All of them were potential bacterial strains derived from cellulose supplemented screening media. Optically, 2HPCS1R4 showed the most abundant hydrophobic inclusion aggregate in comparison to the other two isolates. There are numerous types of hydrophobic inclusion known so far. Rhodococus opacus strain PD630 forms inclusion bodies which consists of several agglomerations of fat bodies triglycerides. They are fully filled the cytoplasm of the cells and between inclusion bodies were bordered only with wall membrane layer separating them (Alvarez et al. 1996). Some Actinobacter-like A. calcoaceticus ADP 1 showed less dense hydrophobic inclusions (Wältermann et al., 2005). They are separated each other and formed spherical disc shape similar to 2HPCS1R4 as shown in Figure 1B, blue and red arrows. In some colonies A. calcoaceticus ADP 1 lipid body inclusion showed only single colony as shown in 1LPCS2R2 and 1LPCS2R14. However, in this study, the identity of the three selected bacteria was not yet elucidated. In the 1LPCS2R2 and 1LPCS2R14, the whole cytoplasm seemed to illuminate fluorescence light and it almost encased the signal from the lipid bodies. Spiekermann et al. (1999) have been reported that nile red staining is not effective to detect hydrophobic inclusion in the gram-positive bacteria. The gram analysis of 1LPCS2R2 and 1LPCS2R14 showed that these bacteria were gram-positive (data not shown), therefore the background signal was very high. 


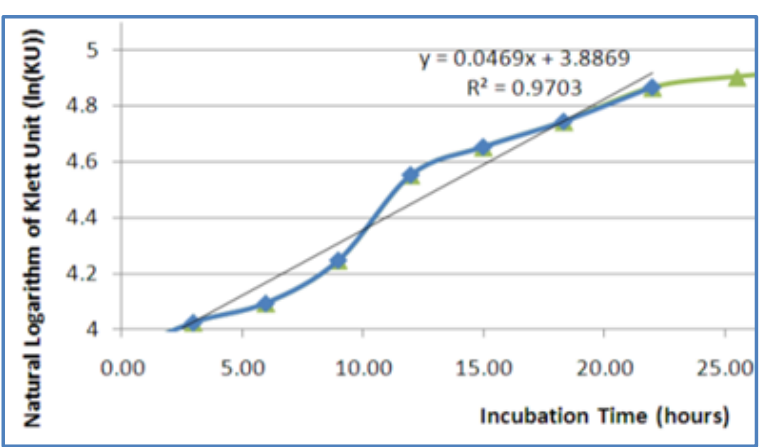

[A]

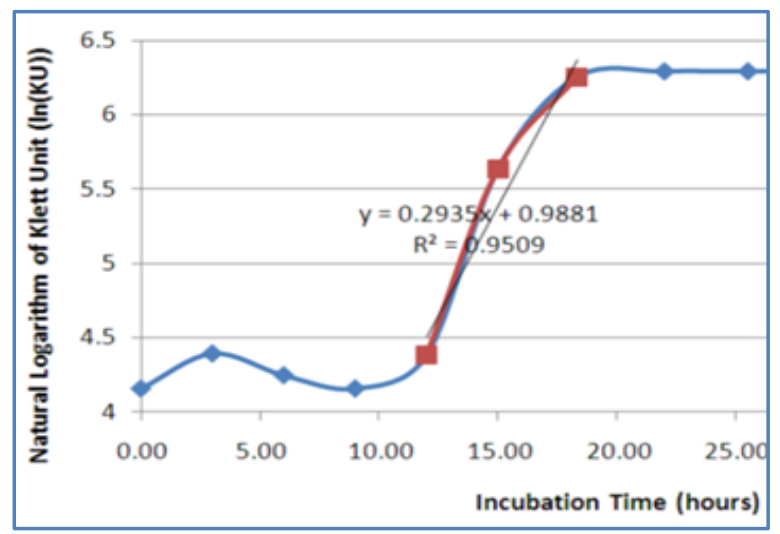

$[\mathrm{C}]$

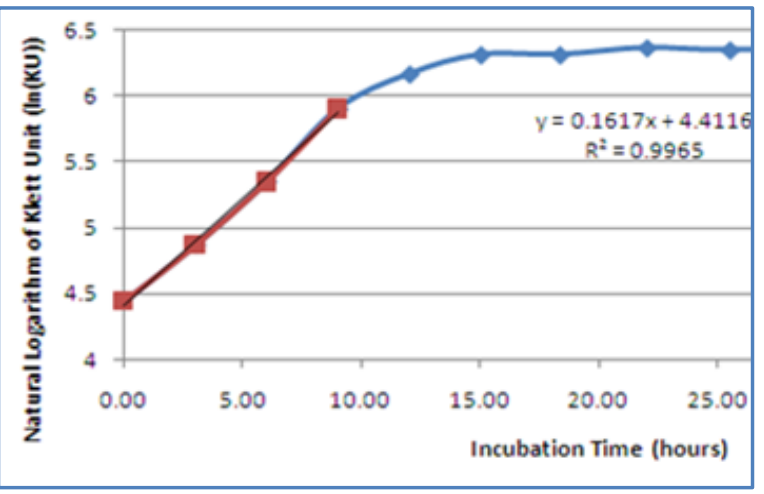

[E]

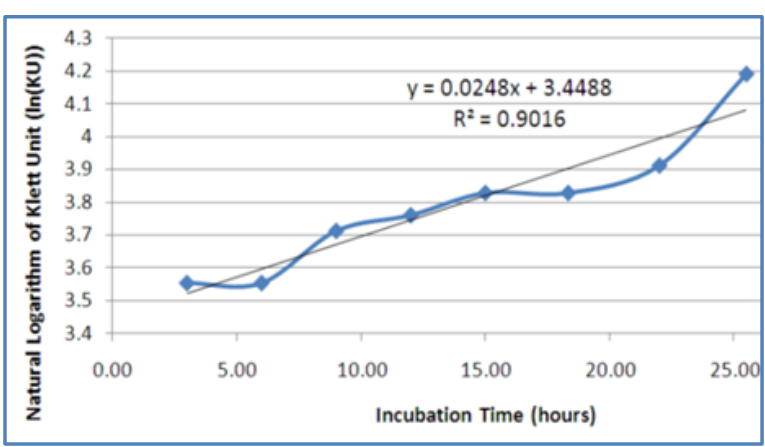

[B]

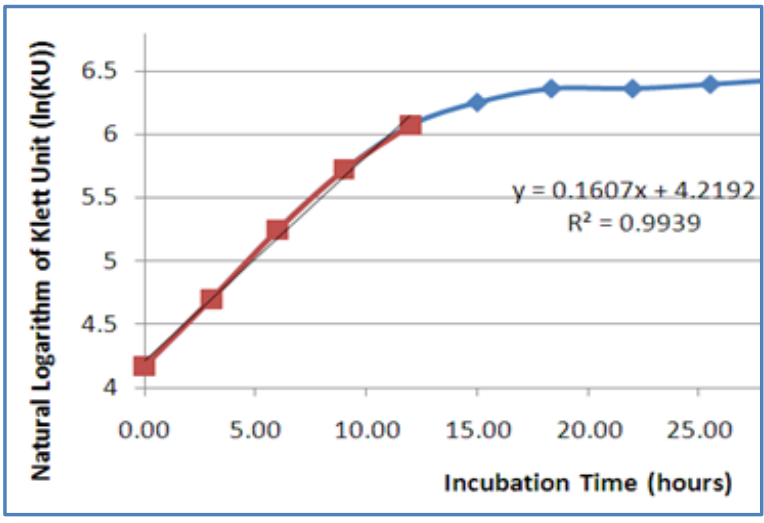

[D]

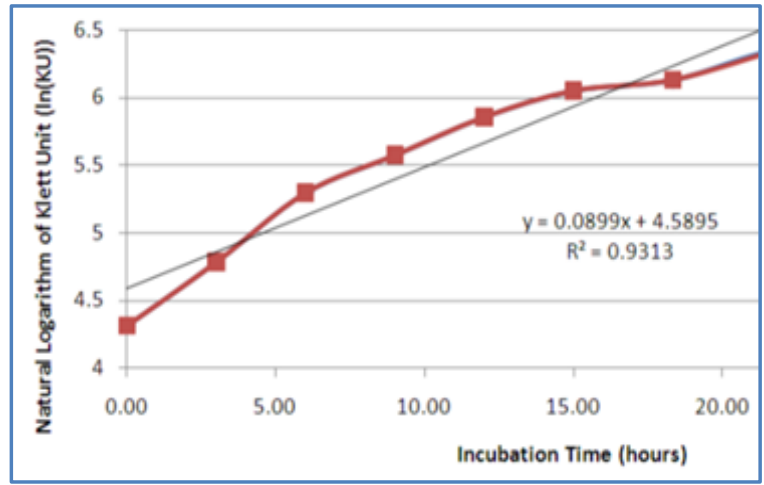

$[\mathrm{F}]$

Figure 7 Growth Curve of Selected Bacterial Isolates.

[(A) 1LPCS2R14 grown in 2\% (w/v) of glucose as sole carbon source. Graphical plot of natural logarithm of klett unit vs incubation time indicated early log phase spanned from $3^{\text {rd }}$ hours to $23^{\text {rd }}$ hours. (B) $1 L P C S 2 R 4$ grown in $2 \%$ (w/v) xylose as sole carbon source. Log phase emerged irregularly throughout the growth phase. (C) 1LPCS2R2 incubated in $2 \%(w / v)$ glucose as sole carbon source. This bacteria, when was grown in glucose, adopted common growth phase. (D) 1LPCS2R2 incubated in 2\% (w/v) xylose. Log phase was occurred already at the early phase of the bacterial growth (until $14^{\text {th }}$ hours). (E) 2 HPCS1R14 incubated in $2 \%$ (w/v) glucose. Log phase started at directly after inoculation and stopped at $10^{\text {th }}$ hours of incubation time. (F) 2HPCS1R14 incubated in 2\% (w/v) xylose. Log phase appeared throughout the measurement (until $22^{\text {nd }}$ hours of incubation time). Afterwards the growth curve became steady.]

Alternative method for identification of lipid substances in bacteria is sudan black staining (Hartman 1940). However, this technique cannot be used for characterization of hydrophobic inclusion in viable bacterial cells, because it requires replica that may increase the complication of the screening method which is unfavorable when the study has to deal with large number of bacterial strains. Nile red offers practical solution for large scale screening of hydrophobic-containing 
microorganisms. However, the limitation of using the dye for gram-positive bacteria can be problematic. Example of these bacteria derived from genus Nocardia and Rhodococcus which are known as lipid-accumulating strains (Alvarez et al. 1997).

Therefore establishment of alternative lipophilic dye that can be used to screen lipid-containing viable gram-positive bacterial cells is essential. In this study, TLC was preferred as low cost technique to screen large number of bacteria derived from fluorescence microscopy initial selection for their ability to accumulate hydrophobic substances. The results showed that an unknown substance was found in 1LPCS2R2. The hydrophobic substances derived from the cells showed two overlapped discrete bands. These spots had comparable retardation factor with the reference TAG. The GC-MS analysis revealed that collection of various lipid with various alkyl length (C14 - C17) was observed. It was not clear whether the substance was TAG, because it was subjected to methanolysis which convert the chemical nature of nonvolatile lipid to volatile compound, fatty acid methyl ester.

This study evaluated also the prospect of the screened microorganisms for industrial application. Growth rate in the fermentation condition should be high to meet the requirement for industrial application. Therefore, kinetic study of the selected bacterial candidate was performed with glucose and xylose as sole carbon source. The selection was based on the fact that both sugars are the most available monosaccharide on the Earth. The result of the kinetic study with the isolated bacteria showed that 1LPCS2R2 was the fastest growth bacteria $\left(0.29 \mathrm{~h}^{-1}\right)$. This isolates showed regular defined lag, $\log$, and stationary phase, while the other did not show such characteristic. However, the doubling rates of the isolate were reduced to half when the isolate was incubated with xylose. The utilization of xylose requires the ability of the microorganisms to adopt xylose isomerase, Weimberg or $\mathrm{XR} / \mathrm{XDH}$ pathways (xylose reductase and xylitol dehydrogenase enzymes) (Fraenkel \& Vinopal 1973; Radek et al. 2014; Sànchez-Nogué \& Karhumaa, 2015). Some bacteria, such as E. coli, prefer to utilize glucose, using glycolytic pathway which end up in tricarboxylic acid cycle, than xylose (Desai \& Rao, 2010). This bacterium has carbon catabolite repression (CCR) that causes sequential consumption of glucose and xylose. The latter is a major component of hemicellulose with diverse proportion which is depended on type of the woods. Softwood comprises of maximum $10 \%$ $(\mathrm{w} / \mathrm{w})$ and hardwood $25 \%(\mathrm{w} / \mathrm{w})$ dry weight of xylose (Sànchez-Nogué \& Karhumaa, 2015).

In conclusion, the study demonstrated an effort to isolate new strains that utilized wood derived sugars which are majority component of lignocellulosic biomass and accumulated TAG which are feedstock for biodiesel production. Fluorescence microscopy revealed three isolates that accumulated considerable amount of hydrophobic compound. Two isolates, 1LPCS2R2 and 1LPCS2R14, seemed to show signals derived from hydrophobic-like membrane-bound substances which is typical for gram-positive bacteria. TLC study showed that two overlapping discrete bands were observed for 1LPCS2R14 and 1LPCS2R2 whereas 2HPCS1R4 showed only single band with the height just above the reference band of lipid. GC analysis confirmed the presence of the lipid that consisted of different C14-C16 fatty acid length. Growth kinetic analysis showed that 1LPCS2R2 was the most rapidly growing isolate among the three in two model carbon sources (glucose and xylose). The result of study proposed strain that can be used for biodiesel production.

\section{Conflict of interest}

Authors would hereby like to declare that there is no conflict of interests that could possibly arise.

\section{References}

Alvarez HM, Mayer F, Fabritius D, Steinbuechel A (1996) Formation of intracytoplasmic lipid inclusions by Rhodococcus opacus strain PD630. Archives of Microbiology 165 : 377-386, DOI 10.1007/s002030050341.

Alvarez HM, Kalscheuer R, Steinbuchel A (1997) Accumulation of storage lipids in species of Rhodococcus and Nocardia and effect of inhibitors and polyethylene glycol. Europian Journal of Lipid Science and Technology 99:239246. DOI: 10.1002/lipi.19970990704

Brethauer S, Studer MH (2015) Biochemical Conversion Processes of Lignocellulosic Biomass to Fuels and Chemicals - A Review. CHIMIA International Journal for Chemistry 69: 572-581, DOI 10.2533/chimia.2015.572.

Bugg TDH, Ahmad M, Hardiman EM, Rahmanpour R(2011) Pathways for degradation of lignin in bacteria and fungi. Natural Product Reports 28: 1883. DOI 10.1039/c1np00042j.

Cara C, Ruiz E, Oliva JM, Saez F, Castro E (2008) Conversion of olive tree biomass into fermentable sugars by dilute acid pretreatment and enzymatic saccharification. Bioresource $\begin{array}{lllll}\text { Technology } & 99 & \text { : } & 1869-1876 . & \text { DOI }\end{array}$ 10.1016/j.biortech.2007.03.037.

Desai TA, Rao CV (2010) Regulation of arabinose and xylose metabolism in Escherichia coli. Applied and Environmental Microbiology76: 1524-1532. DOI 10.1128/AEM.01970-09.

Food and Agriculture Organization (2016) Production quantities by country (palm oil). available on http://faostat3.fao.org/browse/Q/QC/E,accessed on 01 March 2016.

Fraenkel DG, Vinopal RT (1973) Carbohydrate Metabolism in Bacteria. Growth (Lakeland) 27:69-100.

Hartman TL (1940) The Use of Sudan Black B as a Bacterial Fat Stain. Stain Technology 23-28. DOI 10.3109/10520294009110328. 
Ibrahim MHA, Steinbuechel A (2009) Poly(3hydroxybutyrate) production from glycerol by Zobollella denitrificans MW1 via high-cell density fed-batch fermentation. Applied and Environmental Microbiology. DOI10.1128/AEM.01162-09

Jönsson LJ, Martín C (2015) Pretreatment of lignocellulose: Formation of inhibitory by-products and strategies for minimizing their effects. Bioresource Technology 199: 103112. DOI 10.1016/j.biortech.2015.10.009.

Kemenperin Perindustrian dan Perdagangan (2016) Perkembangan Ekspor Indonesia Berdasarkan Sektor. Ministry of Industry. http://kemenperin.go.id/statistik/peran.php?ekspor=1, accessed on 26 April 2016.

Krawczyk T (1996) Biodiesel - Alternative fuel makes inroads but hurdles remain. Inform 7: 801-829, DOI .

Nicholson CA, Fathepure BZ (2004) Biodegradation of benzene by halophilic and halotolerant bacteria under aerobic conditions. Applied and Environmental Microbiology 70 : 1222-1225. doi: 10.1128/AEM.70.2.1222-1225.2004.

Radek A, Krumbach K, Gaetgens J, Wendisch VF, Wiechert W, Bott M, Noack S, Marienhagen J (2014) Engineering of Corynebacterium glutamicum for minimized carbon loss during utilization of d-xylose containing substrates. Journal of Bacteriology 192:156-160, DOI 10.1016/j.jbiotec.2014.09.026.

Sànchez-Nogué V, Karhumaa K (2015) Xylose fermentation as a challenge for commercialization of lignocellulosic fuels and chemicals. Biotechnology Letters 37 : 761-772. DOI 10.1007/s10529-014-1756-2.
Schlegel HG, Kaltwasser H, Gottschalk G (1961) Ein Submersverfahren zur Kultur wasserstoffoxydierender Bakterien: Wachstumsphysiologische Untersuchungen. Archiv für Mikrobiologie 38 :209-222. DOI 10.1007/BF00422356.

Spiekermann P, Rehm BH, Kalscheuer R, Baumeister D, Steinbuechel A (1999) A sensitive, viable-colony staining method using Nile red for direct screening of bacteria that accumulate polyhydroxyalkanoic acids and other lipid storage compounds. Archives of microbiology $171: 73-80$.

Uthoff S, Stöveken T (2005) Thio wax ester biosynthesis utilizing the unspecific bifunctional wax ester synthase/acyl coenzyme A: diacylglycerol acyltransferase of Acinetobacter sp. strain ADP1. Applied and Environmental Microbiology 71 : 790-796. DOI 10.1128/AEM.71.2.790.

Wältermann M, Hinz A, Robenek H, Troyer D, Reichelt R, Malkus U, Galla HJ, Kalscheuer R, Stoeveken T, Landenberg Pv, Steinbuechel A (2005) Mechanism of lipid-body formation in prokaryotes: How bacteria fatten up. Molecular Microbiology 55 : 750-763. DOI $10.1111 / \mathrm{j} .1365-$ 2958.2004.04441.x.

Wyman CE (2003) Potential Synergies and Challenges in Refining Cellulosic Biomass to Fuels, Chemicals, and Power. Biotechnology Progress 19 : 254-262. DOI 10.1021/bp0256541.

Yousuf A (2012) Biodiesel from lignocellulosic biomass Prospects and challenges. Waste Management 32 : 2061-2067. DOI 10.1016/j.wasman.2012.03.008. 